\title{
Economic dimension of the right to sustainable development: good governance and human security
}

\author{
Anahita Seifi ${ }^{1,}{ }^{*}$, Najmeh Razmkhah ${ }^{2}$, and Dmitri Pletnev ${ }^{3}$ \\ ${ }^{1}$ Allameh Tabataba'i University, Dehkade-ye Olympik, West Hemmat Highway, Tehran, \\ 1489684511, Iran \\ ${ }^{2}$ Payame Noor University, Minn City,Artesh Blvd, Tehran,19395-4697,Iran \\ ${ }^{3}$ Chelyabinsk State University, 129, Br. Kashirinykh st., 454001, Chelyabinsk, Russia
}

\begin{abstract}
The enjoyment of human rights by human beings is a goal which pursued by the right to development through the process of development. By emphasizing the collective spirit and recognizing individual and collective rights and a comprehensive approach to the right to development and strengthening the power of man and society that is reflected in the comprehensive approach to security, can motivate human beings to achieve development, peace and security Provide stable. This paper examines the relationship between development, good governance and economic security. Underdevelopment is the bedrock of insecurity, in other words, development is a prerequisite for security. The root of all insecurity and instability is poverty, and without development there can be no security. There is a link between the right to development and security and the components of good governance, and they reinforce each other. In this article, One of the indicators of the right to development is good governance and its relation to economic security everywhere. Good governance has a positive effect on the implementation of the right to development and access to security.
\end{abstract}

\section{Introduction}

Development can be considered as a process by which the totality of human rights is realized, or in other words, the realization of human rights requires the development of human societies in all economic, social, political and cultural dimensions. However, in the last two decades, the concept of the "right to development" has received a lot of attention, and especially its proponents consider it as a fundamental human right. In recent years, the definition of development has evolved to include favorable conditions, such as poverty alleviation and social justice. Some argue that development increases the wealth and wellbeing of the minority, rather than reducing the poverty of the majority. Therefore, policies should be based on human development, and reducing human suffering and not increasing it. Achieving economic growth, i.e per capita population growth, annual GDP growth, reducing absolute poverty, expanding social services such as public access to education,

*Corresponding author: a.seifi@atu.ac.ir 
health, communications and information, reducing inequality, i.e income and wealth disparities, expanding democracy and Social participation, as a factor that strengthens and guarantees economic development, is one of the goals of development, and all of these pursue a single goal and that is achieving a society in which human beings are the basic principle and can meet the needs of Satisfy themselves materially and spiritually $[15, \mathrm{p}$ : 20]. We live in a world that is witnessing fundamental change, a world that has become a vast global market under the influence of a complex financial system and information technology developments. The phenomenon of globalization has created new patterns of interaction between peoples and governments, which on the one hand promises unprecedented opportunities for progress in the form of greater freedoms, and on the other hand a more complex risk. The emergence of many challenges in domestic and international societies is accompanied by a deepening of the economic problems of the most vulnerable among them.

Billions of people around the world are still living in extreme poverty and the deep gap between rich and poor countries is widening. Its underdevelopment, globalization, and rapid developments have posed particular challenges to international human rights. These issues shift the traditional focus on human rights to issues such as trade, cooperation, and the development of monetary, fiscal, foreign debt, transnational corporations, and environmental policies, and the traditional government-centered framework shifts to human rights responsibilities. Another human being gives actors.

In the age of globalization, the traditional approach to security, that is, hard security from which the military concept is inferred and is primarily concerned with government security, is being replaced by new approaches to soft security. This type of security is linked to human beings, progress and development. Koichiro and Matsura, UNESCO Director-General, link the concept of human security to development and argue that lasting peace will not be possible without indigenous development that can eradicate poverty and deprivation. Poverty is the worst form of human rights violation. If a broad consensus can be reached on international cooperation to eradicate poverty, it will be most beneficial to the realization of the right to development (UN.DOC.E / C12 / 2001 / Para.4). Underdevelopment is the bedrock of insecurity, in other words, development is a necessary precondition for security. The root of all insecurity and instability is poverty, and without development there can be no security. Human rights are absolutely vital in creating human security. In practice, security policies should be set very closely in relation to the strategy of improving the human rights situation, democracy and development. Studies show that security is one of the most important factors in the growth and development of countries The establishment of security in society is affected by several factors The government is one of the most important of these. The most important economic effects of security are crystallized in investment and economic growth. Investment plays an important role in economic growth and development Creating security and confidence in countries is essential for the presence of investors, so a secure economic environment It is a key factor for sustainable growth and development in countries. Increasing economic security by reducing pessimism contributes to the expected return on investment and increasing private investment

Undesirable development or underdevelopment as the main cause of deprivation, which means reducing the acceptable level of the quality of life and the guarantee of fundamental human rights. To change the unfavorable conditions, it is necessary to change the structure of the global community This restructuring should basically be development-oriented with an emphasis on its human rights approach. It is not possible to combat these aforementioned problems except in the light of international solidarity as the basis of the right to development.

The concept of "right to development" was first introduced by the Senegalese lawyer 
Kabam Bai in 1972 . Prior to 1986, the concept of development was considered only from the economic aspect, which was the growth of national production and exports of countries. The Declaration of the Right to Development was adopted by the United Nations General Assembly on December 4, 1986 [8]. From this date, the concept of the right to development as an inalienable human right came into being, It has been endorsed in other declarations, declarations and resolutions [12]. Declaration of the right to development, by declaring the right to development as an undeniable right of human rights, According to which every person and all people have the right to participate in and enjoy political, economic, social and cultural development, which was a turning point. Since the adoption of the 1986 Declaration of the Right to Development, this issue has always been emphasized and explained at important international human rights conferences and summits (A / RES / 60 / 251,151,156 March 2006).

In the independent expert reports, the right to development is defined based on the introduction and various articles of the 1986 Declaration. The right to development is an inalienable human right Whereby every human being and all nations have contributed and enjoy political, cultural, social and economic development in which all human rights and fundamental freedoms are fully guaranteed (UN.DOC, E / CN.4 / 2002). This definition contains several basic elements: Development of a comprehensive process that goes beyond mere economic issues to include socio-political and cultural issues with the aim of continuous improvement, ie regular and gradual improvement of the welfare of the people.

In this development process, it must be genuinely participatory and the benefits resulting from the continuous improvement of the welfare and happiness of all people to be distributed fairly and participatory distribution of benefits is a feature of a process called right-centered. This is in line with human rights standards [12].

The human rights approach to development sees development as a process in which human rights standards are addressed, empower vulnerable and poor people in society and eliminate social injustice. To achieve such development, People should have equal opportunities to invest, use their talents and abilities, participate in decision-making and enjoy human rights, political and economic freedoms, health care and education [18, p.1]. Human rights, along with development and security, form the three pillars of the United Nations. According to Mr. Kofi Annan, development and security are necessary for each other and without human rights, none of them is possible.

\section{Results}

The deepest meaning of development and human rights is related to increasing human capabilities, the ability of the people to choose, to promote social progress and to improve living standards and greater freedom, as set out in the Universal Declaration of Human Rights, Therefore, the ultimate goal is to increase human capabilities. Poverty and deprivation are the biggest obstacles to human rights [9, pp.17-19]. This goal will not be achieved if economic, social, cultural, civil and political human rights are not promoted and realized together. The discourse analysis of this debate focuses on the doctrine of "human security" from a "developmental" perspective, Which does not reflect the dominant government-centered perception in terms of not being accountable to what is happening in the field of collective rights within countries [14, pp. 186-198]. Mahboob al-Haq proposes human security as a new security model and said"The world is entering a new era in which the concept of security will change, Security is no longer just territorial security or territory or territory, but security through development, not weapons, Security for all people and everywhere, whether in their homes, on the streets or in relation to their jobs and their environment. In human security, man and his security are considered as central issues, However, human security is a controversial concept " . The concept of human security 
encompasses all aspects of human rights, including: Meeting basic needs, political aspirations, freedom, society, freedom from fear and freedom from poverty at the same time. In this approach, security becomes comprehensive, A situation in which individual citizens live in peace, freedom and security and are fully involved in the governance process. Access to basic resources and necessities of life, including health and education and the eradication of poverty, is one of its goals.

\subsection{Human security}

Human security calls for shifting attention from government-centered to human-centered attitudes in security approaches $[19,13]$. Human security means: understanding new threats beyond traditional forms of violence, understanding new determinants of security and government vote (with emphasis on individuals and communities), understanding the interrelationship between development, human rights and security Human security seeks to make changes in the way security is provided by placing the human person at the center of security concerns [3, PP.47-8]. Threats to human security are direct and indirect threats. Direct security threats are deliberately posed by a group such as terrorists, insurgents or militias, or the government. Direct threats are often accompanied by violence, although they can include other forms such as intentional social or economic exclusion policies. Indirect or structural threats, such as economic crisis, rising crime, environmental consequences, discrimination by political leaders, unintended consequences [1].

\subsection{The relationship between economic security, development and good governance}

Good governance and the right to development are two interrelated concepts, Lack of good governance will severely limit sustainable development and prevent it. [6]. Good governance provides the basis for government accountability and law-abiding behavior [8, p.30]. The main components and foundations of good governance are: participation, Transparency, efficiency, non-discrimination and minimization of corruption in society and Paying attention to the views of minorities and hearing the voice of the vulnerable class of society [5, p.15]. Without the rule of law, transparency and respect for human rights and progress will be difficult. World leaders at the UN World Summit in 2005 emphasis on the rule of law at the national and international levels, to grow economically and eradicate poverty. Weak governance is one of the most important issues. Research conducted by some research institutes are recognized worldwide, Positive correlation between rule of law and improved governance and revenue growth. Sovereignty control and accountability help promote socio-economic rights and the right to development.

The right to development considers the following principles : Justice - Participation, Transparency, Anti-Corruption and Rule of Law - all of which are components of good governance. Corruption exists as a pervasive phenomenon and a deterrent to development in most societies. The level of corruption in society is directly related to the time spent to raise development indicators Less corruption and a stable political system equate to attracting more capital. Corruption reduces the likelihood of government action. In good governance in addition to the government, civil society and citizens also play an important role in realization of good governance.

They also provide opportunities for people in the community to develop their capacities and improve their living standards. Civil society based on civil ethics and the rule of law can lead to good governance, Economic, social and civic parties, unions and organizations are the necessary bases for economic and social development. Strong civil society participation is effective in achieving good governance, because important actors will enter 
the scene and public investment will be guaranteed. Good governance can lead to economic growth as a result of labor division, more productive investment, and the implementation of sound social policies.

High level of human capital and municipal services, trained workforce with information technology and Public institutions to oversee the public sector had played a great role in improving institutions and ensures that policies are formulated correctly. Actually the result of the relationship between economics and politics must be security. Prioritize for economic and welfare issues, eliminate unemployment and poverty, meet the needs of different segments of society are important aspects of security and a platform for strengthening the country's power at the national and international levels [16]. Economic security is a situation in which the investor has no worries about the return on his investment. Economic security is one of the components of human security that providing this type of security requires a kind of basic and secure income for individuals. Indicators that are sources of threat in this dimension are: Lack of productive employment, job instability, long-term unemployment and Indicators that are sources of threats in this dimension are: lack of food, insufficient access to resources. There is a link between development and security and human rights, and they reinforce each other, and our main task in today's world community is to validate this link [11]. Ultimately, the beneficiary of security must be a human being, and it is an undeniable fact that "there will be no secure government if its people live in insecurity [2]. It should be emphasized, however, that progress in one area reinforces the possibility of progress in another. In the present era, taking care of human security and improving the safety of citizens against all kinds of threats, has become one of the main tasks of governments and governments, and they are obliged to prioritize human security in their policies and plans [7]

Thus, the root of any insecurity and instability is poverty. Adverse economic development or underdevelopment is the main cause of deprivation and violence. Therefore, success in the development path will be possible only with a comprehensive view of the development environment. The role of governments in providing the necessary institutions for development is becoming more important [4]

The approach based on human security, although it accepts the government as the main provider of this security, but for its role, three conditions are mentioned. In the first place, contrary to the realist model, which believes in powerful governments, this approach considers right-based governments to be the most effective and legitimate form of government for ensuring human security. The human security approach argues that even when the government has the capacity to provide human security, it cannot be considered the sole provider of security. Ideally, the government's human security approach portrays the government as part of a cohesive and dynamic political network involving nongovernmental actors such as civil and international and regional organizations, NGOs and individual communities [17]

\section{Conclusions}

Security and development are interconnected, necessary and interdependent concepts, and without security, development will be impossible, and development also plays an important role in establishing security. The human security approach also considers the rule of law to be the most legitimate form of government for economic security. Civil societies and international and regional organizations as well as individuals can help the government increase the level of human security.

People's expectations of the government have changed and governments have to meet the needs of the spread of new technologies and Environmental and security concerns in the style of democratic governments. Good governance at the national and international levels 
is essential to achieving economic security and the right to development. Without good governance, no country can expect to achieve human development. Thus, the right to development, economic security and good governance are interdependent. What is needed here is the commitment of governments to ensure the right to development. Good governance removes obstacles to the implementation of development programs and by providing transparency and accountability, closes the way for irresponsibility in practice, it blocks the possibility of deviating from the plan

\section{References}

1. S. Alkire, A conceptual Framework For Human security, working paper 2 (Center for Research on Inequality, Human security and Ethnicity, CRISE, Queen Elizabeth House, university of oxford, 2003)

2. M. R. Alipour, Proceedings of the International Conference on Human Security in West Asia (Birjand University, 1999)

3. B. Buzan, International Theory: Positivism and Beyond (Cambridge, Cambridge University Press, 1996)

4. M. A. Ghasemi, Quarterly Journal of Strategic Studies 3, 41 (2008)

5. R.M. Gisselquist, Good Governance as a Concept and Why This Matters for Development Policy (World Institute for Development Economics Research, United Nations University, Helsinki, 2012) ISBN978-92-9230-493-5

6. M. Kardos, Procedia- Social and Behavioral sciences 58, 1166-1173 (2012)

7. S. Madani, Serial number report: 6913 Office of Economic Studies (2004)

8. S.P. Marks, Harvard Human Rights Journal 17 (2004)

9. S.P. Marks, The Bangladesh Development studies XXX III, 182 (2010)

10. N. Maldonado, The world Banks Evolving Concept of Good Governance and its Impact on Human Rights (Doctoral Workshop on Development and International organizations Stockholm, Sweden, 2010)

11. B.G. Ramcharan, Conceptualizing Human Security http://www.american.edu/sis/students/sword/Back-Issues/1.pdf

12. S. Arjun, Oxford Development studies 32(2) (2004)

13. S. Motaghi, A. Mottaghi, D. Pletnev, E. Nikolaeva, I. Kapkaev, E3S Web of Conferences 14020, 175 (2020) doi:10.1051/e3sconf/202017514020

14. H. Sharifi Tarazkoohi, Proceedings of the Conference on Government and Guarantees of Economic, Social and Cultural Rights, Faculty of Law and Political Science (University of Tehran Publications, Center for Human Rights Studies, United Nations Development Program, 2011)

15. R. Shirzadi, Modernization of Development and Globalization, Schools, Concepts and Theories (Hagh Yavaran Publishing, 2007)

16. H. Shokooh, Quarterly Journal of Strategic Studies 16(2) (2013)

17. S. Tadjbakhsh, Human Security: Looking back before Looking Forward, ICHSWA Conference (Birjand, 2009)

18. A. Essien, Human Development And Good Governance (Nigerian Case; 1996-2012) (University of Lagos, Lagos, 2012) http://ssrn.com/abstract=2150466

19. A.I. Xavier, Human security perspectives 7(1) (2010) 